\title{
Secondary Metabolites from the Mycelia of the Fungus Monascus pilosus BCRC 38072
}

\author{
Ming-Jen Cheng, ${ }^{a}$ Ming-Der Wu ${ }^{a}$ Ih-Sheng Chen,,${ }^{b, \#}$ and Gwo-Fang Yuan ${ }^{*, a}$ \\ ${ }^{a}$ Bioresource Collection and Research Center (BCRC), Food Industry Research and Development Institute; Hsinchu 300 , \\ Taiwan, Republic of China: and ${ }^{b}$ College of Pharmacy, Kaohsiung Medical University; Kaohsiung 807, Taiwan, Republic \\ of China. Received November 12, 2007; accepted December 11, 2007; published online December 13, 2007
}

Three new compounds, including two phenylacetic acid derivatives, monaspilosin (1) and monaspiloindole (2), and one pyranoindole alkaloid, monaspyranoindole (3), were isolated from the EtOAc-soluble fraction of the MeOH extract of the mycelia of Monascus pilosus BCRC 38072. Twelve known compounds were also obtained in this study. The structures were elucidated by 1D and 2D NMR spectroscopy and mass spectrometry. This is the first report of Monascus metabolites with an indole ring. All isolates were also evaluated for their scavenging properties toward the 2,2-diphenyl-1-picrylhydrazyl radical (DPPH) in TLC autographic and spectroscopic assays.

Key words Monascus pilosus; Eurotiaceae; phenylacetic acid; pyranoindole; 2,2-diphenyl-1-picrylhydrazyl

Monascus has been used in oriental fermented foods for thousands of years. ${ }^{1)}$ Red mold rice fermented with Monascus spp. produces bioactive metabolites such as $\gamma$ aminobutyric acid (GABA), polyketides monacolin $\mathrm{K}$, and some pigments, which, respectively, function as an anti-hypertension agent, ${ }^{2}$ a cholesterol-lowering drug, ${ }^{3-5)}$ and possess antibacterial activity. ${ }^{6}$ Monascus pigments, secondary metabolites possessing mainly azaphilone skeletons, have traditionally been used as natural food colorants. ${ }^{1)}$ Many other metabolites have also been reported in previous research, ${ }^{7-15)}$ most of them isolated from red mold rice obtained from solid fermentation. In contrast, the metabolites contained in the mycelia pellets from submerged cultures have rarely been investigated. The antioxidant effects exhibited in the methanol extract fraction of the mycelia pellets of $M$. pilosus BCRC 38072 were monitored using the 2,2diphenyl-1-picrylhydrazyl (DPPH) free radical scavenging method. ${ }^{16,17)}$ Subsequent chemical examination of the methanol extract of mycelia from $M$. pilosus led to the isolation of two new phenylacetic acid derivatives, monaspilosin (1) and monaspiloindole (2), and one new pyranoindole alkaloid, monaspyranoindole (3), along with twelve known compounds. This paper reports on the isolation, structural elucidation and the DPPH free radical scavenging activity of these fungal metabolites.

\section{Results and Discussion}

Extensive chromatographic purification of the EtOAc-soluble fraction of the $\mathrm{MeOH}$ extract of the pellets of $M$. pilosus afforded fifteen compounds. The new compound $\mathbf{1}$, isolated as colorless oil, was assigned the molecular formula $\mathrm{C}_{16} \mathrm{H}_{16} \mathrm{O}_{3} \mathrm{Na}$ by ESI-MS ([M+Na $]^{+}, m / z$ 279) and HR-ESIMS. IR absorptions were observed at 3403, 1712, 1612, $1514 \mathrm{~cm}^{-1}$ pointing to the presence of hydroxyl, an ester carbonyl group, and a benzene ring. The UV spectrum showed maximum absorption at $277 \mathrm{~nm}$, and a bathochromic shift in alkaline solution indicated the presence of a phenol derivative. ${ }^{18)}$ This was confirmed by the ${ }^{1} \mathrm{H}-\mathrm{NMR}$ spectrum, which showed one proton at $\delta_{\mathrm{H}} 4.90(1 \mathrm{H}$, br s) assigned to $\mathrm{OH}-15$, which disappeared upon addition of $\mathrm{D}_{2} \mathrm{O}$. The ${ }^{1} \mathrm{H}-\mathrm{NMR}$

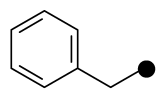

$1 \mathbf{a}$

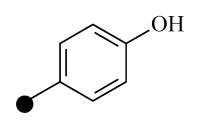

$1 \mathrm{c}$
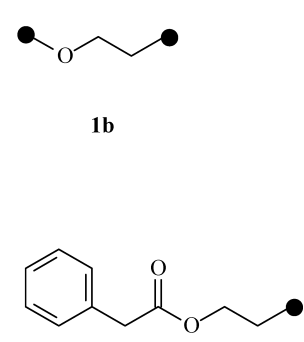

1d spectrum of 1 showed a mono-substituted phenyl moiety at $\delta_{\mathrm{H}} 7.09(5 \mathrm{H}, \mathrm{m}, \mathrm{H}-2-6)$. An $\mathrm{AA}^{\prime} \mathrm{XX}^{\prime}$ pattern at $\delta_{\mathrm{H}} 6.72$, 7.00 (each $2 \mathrm{H}, \mathrm{d}, J=8.8 \mathrm{~Hz}, \mathrm{H}-14,16$ and $\mathrm{H}-13,17$ ) suggested a 1,4-disubstituted benzene ring in $\mathbf{1}$. In addition, the ${ }^{1} \mathrm{H}-\mathrm{NMR}$ and HSQC spectra revealed the presence of a benzylic methylene group $\left[\delta_{\mathrm{H}} 3.60(2 \mathrm{H}, \mathrm{s})\right]$. An oxymethylene unit $\left[\delta_{\mathrm{H}} 4.26(2 \mathrm{H}, \mathrm{t}, J=7.0 \mathrm{~Hz}, \mathrm{H}-10)\right]$ split into a triplet due to coupling with another methylene group $\left[\delta_{\mathrm{H}} 2.84(2 \mathrm{H}, \mathrm{t}\right.$, $J=7.0 \mathrm{~Hz}, \mathrm{H}-11)]$. The above signals and the COSY spectrum established the presence of the partial substructures: fragments, 1a, 1b, and 1c, for compound 1. The entire skeleton of 1 was constructed from the HMBC spectrum (Fig. 2). The ${ }^{2} J$ and ${ }^{3} J$ correlations of the signal at $\delta_{\mathrm{H}} 3.60(\mathrm{H}-7)$ and $\delta_{\mathrm{H}} 4.26(\mathrm{H}-10)$, with the carbon signal at $\delta_{\mathrm{C}} 171.6(\mathrm{C}-8)$, helped to establish the connections of fragments $\mathbf{1 a}$ and $\mathbf{1 b}$ with the carbonyl group at C-8. That is, fragments $\mathbf{1 a}$ and $\mathbf{1 b}$ can be connected to produce $\mathbf{1 d}$. In addition, the cross peak between $\delta_{\mathrm{H}} 2.84(\mathrm{H}-11)$ and $\delta_{\mathrm{C}} 130.0(\mathrm{C}-13,17)$, as well as $\delta_{\mathrm{H}} 4.26(\mathrm{H}-10)$ and $\delta_{\mathrm{C}} 129.6(\mathrm{C}-12)$, suggest that fragments 1c and 1d were linked together at $\mathrm{C}-11$. The structure was further confirmed by ${ }^{13} \mathrm{C}-\mathrm{NMR}$, DEPT, COSY, NOESY (Fig. 1), HSQC, and HMBC (Fig. 2) experiments. Thus, the structure of 1 was determined to be a phenylacetic acid 2-(4-hydroxyphenyl)ethyl ester, and was given the name monaspilosin.

Compound 2, also a colorless oil, was assigned the molecular formula $\mathrm{C}_{18} \mathrm{H}_{17} \mathrm{NO}_{2}$, as deduced by ESI-MS and HRESI-MS. The presence of an ester group was revealed by an 


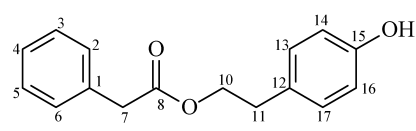

1

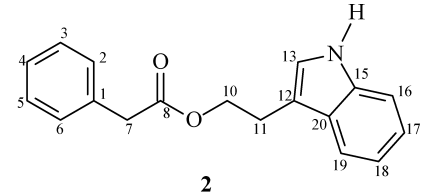

2

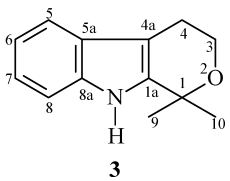

Fig. 1. New Compounds Isolated from Monascus pilosus

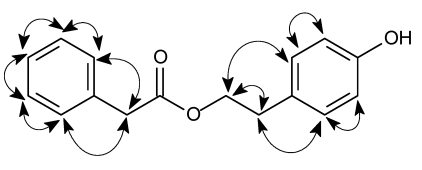

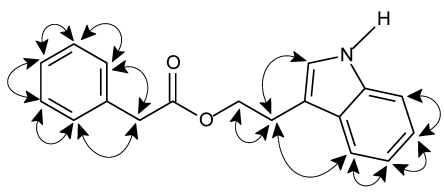

2

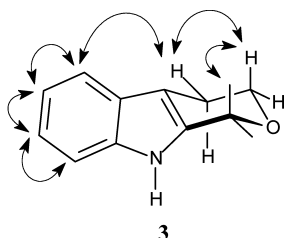

3

Fig. 2. NOESY Interactions of Monaspilosin (1), Monaspiloindole (2), and Monaspyranoindole (3)

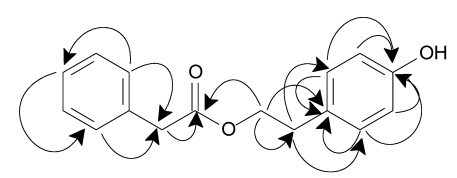

1

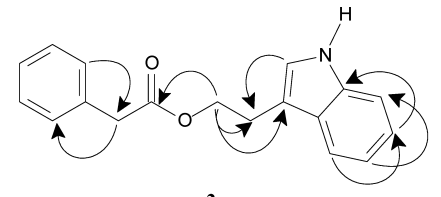

2

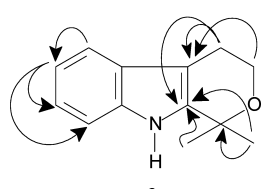

Fig. 3. Major HMBC Connectivities of Monaspilosin (1), Monaspiloindole (2), and Monaspyranoindole (3)

IR absorption at $1716 \mathrm{~cm}^{-1}$ and by a resonance signal in the

${ }^{13} \mathrm{C}$-NMR spectrum at $\delta_{\mathrm{C}} 171.3$. The presence of a $\mathrm{NH}$ group in the molecule was revealed by a band at 3410 (br) $\mathrm{cm}^{-1}$ in the IR spectrum, which was confirmed by the signal at $\delta_{\mathrm{H}}$ $8.00(1 \mathrm{H}$, brs $)$, which disappeared upon addition of $\mathrm{D}_{2} \mathrm{O}$. The UV spectrum showed a maximum absorption at $280 \mathrm{~nm}$, indicating the presence of a phenylacetic acid skeleton. ${ }^{18)}$ The ${ }^{1} \mathrm{H}$-NMR spectrum of compound $\mathbf{2}$ was similar to the above compound, monaspilosin (1), except that the substitutent at $\mathrm{C}-11$ in $\mathbf{2}$ was a $1 H$-indol-3-yl moiety in place of the $p$-hydroxyphenyl group in 1. Signals for the indol-3-yl moiety appeared at $\delta_{\mathrm{H}} 7.13(1 \mathrm{H}$, br t, $J=7.8 \mathrm{~Hz}, \mathrm{H}-18), 7.20(1 \mathrm{H}$, brt, $J=7.8 \mathrm{~Hz}, \mathrm{H}-17), 7.36(1 \mathrm{H}$, brd, $J=7.8 \mathrm{~Hz}, \mathrm{H}-16)$, and $7.61(1 \mathrm{H}$, brd, $J=7.8 \mathrm{~Hz}, \mathrm{H}-19)$, suggesting four coupling aromatic protons along with a nitrogen-bearing olefinic proton at $\delta_{\mathrm{H}} 6.93(1 \mathrm{H}, \mathrm{t}, J=1.8 \mathrm{~Hz}, \mathrm{H}-13)$. The above assignments were verified by NOESY correlations between $\delta_{\mathrm{H}} 3.09$ $(\mathrm{H}-11) / \delta_{\mathrm{H}} 6.93(\mathrm{H}-13)$ and $\delta_{\mathrm{H}} 7.61(\mathrm{H}-19)$, respectively. The olefinic proton signal at $\delta_{\mathrm{H}} 6.93(\mathrm{H}-13)$ was correlated with a methylene carbon at $\delta_{\mathrm{C}} 24.7(\mathrm{C}-11)$, as well as $\delta_{\mathrm{H}} 4.38(\mathrm{H}-$ $10)$ and $\delta_{\mathrm{C}} 112.0(\mathrm{C}-12)$ from the HMBC spectrum, suggesting that the indole moiety linked at $\mathrm{C}-11$. The structure was further confirmed by ${ }^{13} \mathrm{C}-\mathrm{NMR}$, DEPT, COSY, NOESY (Fig. 2), HSQC, and HMBC (Fig. 3) experiments. Thus, the structure of 2 was determined to be a phenylacetic acid $2-(1 \mathrm{H}-$ indol-3-yl)ethyl ester, and designated monaspiloindole. Compound $\mathbf{2}$ was first isolated from a natural source, although it has been mentioned by Yamamoto as a reactant for synthesizing a new class of anti-methicillin-resistant Staphylococcus aureus (anti-MRSA) and anti-vancomycin-resistant enterococci (anti-VRE) agents. ${ }^{19)}$

Compound $\mathbf{3}$ was also isolated as colorless oil. The HR-ESI-MS spectrum gave a molecule ion $[\mathrm{M}+\mathrm{Na}]^{+}$at $\mathrm{m} / \mathrm{z}$ 224.3139, consistent with a molecular formula of $\mathrm{C}_{13} \mathrm{H}_{15} \mathrm{NONa}$. UV spectrum showed maximum absorption at $288 \mathrm{~nm}$, indicating the presence of an indole skeleton. ${ }^{18)}$ Its
IR spectrum revealed $\mathrm{NH}$ absorption at $3320 \mathrm{~cm}^{-1}$. Analysis of the ${ }^{1} \mathrm{H}-\mathrm{NMR}$ spectrum of $\mathbf{3}$ revealed four typical mutually coupling aromatic protons of indole alkaloid at $\delta_{\mathrm{H}} 7.11(1 \mathrm{H}$, td, $J=7.6,1.0 \mathrm{~Hz}, \mathrm{H}-7), 7.17$ (1H, td, $J=7.6,1.0 \mathrm{~Hz}, \mathrm{H}-6)$, $7.33(1 \mathrm{H}, \mathrm{dd}, J=7.6,1.0 \mathrm{~Hz}, \mathrm{H}-5), 7.49(1 \mathrm{H}, \mathrm{dd}, J=7.6$, $1.0 \mathrm{~Hz}, \mathrm{H}-8)$ and one NH group at $\delta_{\mathrm{H}} 7.66(1 \mathrm{H}$, br s, exchangeable with $\mathrm{D}_{2} \mathrm{O}$ ). In addition, the appearance of a set of $\mathrm{A}_{2} \mathrm{X}_{2}$ pattern signals at $\delta_{\mathrm{H}} 2.80(2 \mathrm{H}, \mathrm{t}, J=5.4 \mathrm{~Hz}, \mathrm{H}-4)$ and $4.05(2 \mathrm{H}, \mathrm{t}, J=5.4 \mathrm{~Hz}, \mathrm{H}-3)$, accompanied by a singlet of two methyl groups at $\delta_{\mathrm{H}} 1.57\left(6 \mathrm{H}, \mathrm{s}, \mathrm{CH}_{3}-9,10\right)$. The HMBC correlations (Fig. 3) from $\delta_{\mathrm{H}} 1.57\left(\mathrm{CH}_{3}-9,10\right)$ to $\delta_{\mathrm{C}} 138.9$ $(\mathrm{C}-1 \mathrm{a}) ; \delta_{\mathrm{H}} 2.80(\mathrm{H}-4)$ to $\delta_{\mathrm{C}} 106.9,138.9(\mathrm{C}-4 \mathrm{a}, 1 \mathrm{a})$, and $\delta_{\mathrm{H}}$ $4.05(\mathrm{H}-3)$ to $\delta_{\mathrm{C}} 106.9(\mathrm{C}-4 \mathrm{a})$ verify the junction of the $1,1-$ dimethyldihydropyrano ring to the indole moiety at $\mathrm{C}-1 \mathrm{a}$, and $4 \mathrm{a}$. The other key correlations of HMBC are illustrated in Fig. 3. Based on the above data, the structure of $\mathbf{3}$, named monaspyranoindole, was elucidated as 1,1-dimethyl-1,3,4,9tetrahydropyrano[3,4-b]indole, which was further confirmed by ${ }^{13} \mathrm{C}-\mathrm{NMR}$, COSY, NOESY (Fig. 2), HSQC and HMBC (Fig. 3) experiments. Compound $\mathbf{3}$ was first isolated from a natural source, though it has since been synthesized. ${ }^{20)}$

The other known isolates, $\beta$-sitosteryl stearate, ${ }^{21)}$ a mixture of $\beta$-sitosterol and stigmasterol, ${ }^{22)}$ ergosterol, ${ }^{23)} p$-hydroxybenzoic acid, ${ }^{24)}$ methylparaben, ${ }^{25)}$ trans-caffeic acid, ${ }^{26}$ linoleic acid, ${ }^{27)}$ cyclo-(L-Pro-L-Tyr), ${ }^{28)}$ 5-(hydroxymethyl)furfural, ${ }^{29)}(Z)$-pulchellalactam, ${ }^{30)}$ and $(4 R, 5 S)$-5-hydroxyhexan4 -olide, ${ }^{31)}$ were readily identified by comparison of their physico-chemical, spectroscopic, and mass-spectrometric data with the literature. Except for linoleic acid, this is the first time any of the compounds described above have been isolated from Monascus spp. The radical-scavenging properties of the fifteen compounds were evaluated against the DPPH radical. ${ }^{16)}$ By using DPPH as a TLC spray reagent, $p$ hydroxybenzoic acid and trans-caffeic acid $(5,10 \mu \mathrm{g})$ appeared as strong yellow spots against a purple background, while compound 1 displayed moderate yellow spots, and 
Table 1. ${ }^{1} \mathrm{H}$ - and ${ }^{13} \mathrm{C}-\mathrm{NMR}$ Data for Compounds $\mathbf{1}-\mathbf{3}$ in $\mathrm{CDCl}_{3}(400 \mathrm{MHz})$

\begin{tabular}{|c|c|c|c|c|c|c|}
\hline \multirow{2}{*}{ No. } & \multicolumn{2}{|r|}{1} & \multicolumn{2}{|r|}{2} & \multicolumn{2}{|r|}{3} \\
\hline & $\delta_{\mathrm{C}}$ & $\delta_{\mathrm{H}}($ mult; $J, \mathrm{~Hz})$ & $\delta_{\mathrm{C}}$ & $\delta_{\mathrm{H}}(\mathrm{mult} ; J, \mathrm{~Hz})$ & $\delta_{\mathrm{C}}$ & $\delta_{\mathrm{H}}(\mathrm{mult} ; J, \mathrm{~Hz})$ \\
\hline 1 & 133.9 & - & 134.1 & - & 71.8 & - \\
\hline $1 \mathrm{a}$ & - & - & & - & 138.9 & - \\
\hline 2 & 129.3 & $7.09(\mathrm{~m})$ & 129.3 & $7.30(\mathrm{~m})$ & & - \\
\hline 3 & 127.1 & $7.09(\mathrm{~m})$ & 127.0 & $7.30(\mathrm{~m})$ & 60.5 & $4.05(\mathrm{t}, 5.4)$ \\
\hline 4 & 128.5 & $7.09(\mathrm{~m})$ & 128.5 & $7.30(\mathrm{~m})$ & 22.4 & $2.80(\mathrm{t}, 5.4)$ \\
\hline $4 a$ & - & - & & - & 106.9 & - \\
\hline 5 & 127.1 & $7.09(\mathrm{~m})$ & 127.0 & $7.30(\mathrm{~m})$ & 110.8 & $7.33(\mathrm{dd}, 7.6,1.0)$ \\
\hline $5 \mathrm{a}$ & - & - & & - & 127.0 & - \\
\hline 6 & 129.3 & $7.09(\mathrm{~m})$ & 129.3 & $7.30(\mathrm{~m})$ & 121.7 & $7.17(\mathrm{td}, 7.6,1.0)$ \\
\hline 7 & 41.4 & $3.60(\mathrm{~s})$ & 41.5 & $3.63(\mathrm{~s})$ & 119.6 & $7.11(\mathrm{td}, 7.6,1.0)$ \\
\hline 8 & 171.6 & - & 171.6 & - & 118.3 & $7.49(\mathrm{dd}, 7.6,1.0)$ \\
\hline $8 \mathrm{a}$ & - & - & & - & 135.7 & - \\
\hline 9 & - & - & & - & 27.9 & $1.57(\mathrm{~s})$ \\
\hline 10 & 65.6 & $4.26(t, 7.0)$ & 65.0 & $4.38(\mathrm{t}, 7.0)$ & 27.9 & $1.57(\mathrm{~s})$ \\
\hline 11 & 34.1 & $2.84(\mathrm{t}, 7.0)$ & 24.7 & $3.09(\mathrm{td}, 7.0,1.8)$ & - & - \\
\hline 12 & 129.6 & - & 112.0 & - & - & - \\
\hline 13 & 130.0 & $7.00(\mathrm{~d}, 8.8)$ & 122.0 & $6.93(\mathrm{t}, 1.8)$ & - & - \\
\hline 14 & 115.3 & $6.72(\mathrm{~d}, 8.8)$ & & - & - & - \\
\hline 15 & 154.2 & - & 136.1 & - & - & - \\
\hline 16 & 115.3 & $6.72(\mathrm{~d}, 8.8)$ & 111.1 & 7.36 (br d, 7.8) & - & - \\
\hline 17 & 130.0 & $7.00(\mathrm{~d}, 8.8)$ & 122.1 & $7.20(\mathrm{brt}, 7.8)$ & - & - \\
\hline 18 & - & - & 119.4 & 7.13 (brt, 7.8) & - & - \\
\hline 19 & - & - & 118.8 & $7.61(\mathrm{brd}, 7.8)$ & - & - \\
\hline 20 & - & - & 127.4 & - & - & - \\
\hline OH-15 & - & 4.90 (br s) & & - & - & - \\
\hline $\mathrm{NH}$ & - & - & & 8.00 (brs) & - & 7.66 (brs) \\
\hline
\end{tabular}

other compounds did not react with the radical. The phenol derivatives $p$-hydroxybenzoic acid and trans-caffeic acid were more active than $\mathbf{1}$ in the above concentration range. The free radical scavenging effects of the isolates (compound 1, $p$-hydroxybenzoic acid and trans-caffeic acid), corresponding to the intensity of quenching of the DPPH radical, were evaluated by spectroscopic assay. At a concentration of $50 \mu \mathrm{M}$, the test compounds showed moderate DPPH radical scavenging activity, with 40, 65, and $87 \%$ inhibition for compound 1, $p$-hydroxybenzoic acid and trans-caffeic acid, respectively, with trans-caffeic acid the most active compound in this study.

In summary, most of recent studies on secondary metabolites from Monascus have investigated red mold rice and whole broth. These metabolites are azaphilone, ${ }^{15)}$ furanoisophthalides, ${ }^{15)}$ amino acid, ${ }^{13,15)}$ polyketides, ${ }^{1)}$ and fatty acids. ${ }^{1)}$ Nevertheless, the chemical characteristics, as well as the biological activities, of many Monascus metabolites still remain unclear. In this study we focus on the secondary metabolites appearing in the mycelia of Monascus submerged culture, which has seldom been reported on. The three metabolites 1, $\mathbf{2}$ and 3, phenyl ester, indole, and pyranoindole alkaloid found in this study are new, naturally occurring compounds. Interestingly, this is the first report of an indole alkaloid isolated from this Monascus spp. Compound 1, $p$-hydroxybenzoic acid and trans-caffeic acid were found to have significant antioxidant properties, as determined by experiments with 2,2-diphenyl-1-picrylhydrazyl (DPPH), which suggests their ability to efficiently scavenge free radicals. Compounds $\mathbf{1}$ and $\mathbf{2}$ have similar structures, but the latter does not show the ability to efficiently scavenge free radicals, which implies that the presence of a phenol group is crucial for activity. The hydrogen donating ability was associated with the radical scavenging effects of antioxidants on the DPPH radical. Structures containing phenolic hydroxyl and carboxylic acid moieties have long been recognized to function as electron or hydrogen donors. Thus, the higher DPPH radical scavenging activity of $p$-hydroxybenzoic acid and trans-caffeic acid may be related to the phenolic and carboxylic acid groups present in the molecules. These results suggest that Monascus has distinct and diverse metabolites which arise under different fermentation conditions. It may therefore be possible to find more new bioactive natural products by cultivating Monascus under different conditions.

\section{Experimental}

General All melting points were determined on a Yanaco micro-melting point apparatus and were uncorrected. Optical rotations were measured on a Jasco P-1020 digital polarimeter, UV spectra were obtained on a Jasco UV240 spectrophotometer in $\mathrm{MeOH}$, and IR spectra ( $\mathrm{KBr}$ or neat) were taken on a Perkin-Elmer System 2000 FT-IR spectrometer. 1D $\left({ }^{1} \mathrm{H},{ }^{13} \mathrm{C}\right.$, DEPT) and 2D (COSY, NOESY, HSQC, HMBC) NMR spectra using $\mathrm{CDCl}_{3}$ and $\mathrm{CD}_{3} \mathrm{OD}$ as solvent were recorded on a Varian Unity Plus $400(400 \mathrm{MHz}$ for ${ }^{1} \mathrm{H}-\mathrm{NMR}, 100 \mathrm{MHz}$ for $\left.{ }^{13} \mathrm{C}-\mathrm{NMR}\right)$ and Varian INOVA-500 $(500 \mathrm{MHz}$ for ${ }^{1} \mathrm{H}-\mathrm{NMR}, 125 \mathrm{MHz}$ for ${ }^{13} \mathrm{C}-\mathrm{NMR}$ ) spectrometer. Chemical shifts were internally referenced to the solvent signals in $\mathrm{CDCl}_{3}\left({ }^{1} \mathrm{H}, \delta 7.26 ;{ }^{13} \mathrm{C}, \delta 77.0\right)$ with Tetramethylsilane (TMS) as the internal standard. Low-resolution ESIMS spectra were obtained on an API 3000 (Applied Biosystems) and highresolution ESI-MS spectra on a Bruker Daltonics APEX II 30e spectrometer. Low-resolution EI-MS spectra were recorded on a Quattro GC/MS spectrometer having a direct inlet system. Silica gel (70-230, 230 - 400 mesh) (Merck) was used for column chromatography, and silica gel 60 F-254 (Merck) was used for TLC and prep. TLC. For radical scavenging TLC autographic assay, DPPH (Sigma) was used as spray reagent.

Microorganism Monascus pilosus BCRC 38072 was used throughout this study, and specimens deposited at the Bioresource Collection and Research Center (BCRC) of the Food Industry Research and Development Institute. 
Media The inoculum's medium contained: malt extract, $3 \mathrm{~g}$; yeast extract, $3 \mathrm{~g}$; glucose, $5 \mathrm{~g}$; agar, $1.5 \mathrm{~g}$; and distilled water 11 . The initial $\mathrm{pH}$ of the medium was 8 . The synthetic culture medium contained: glucose, $20 \mathrm{~g}$; monosodium L-glutamate (MSG), $10 \mathrm{~g} ; \mathrm{K}_{2} \mathrm{HPO}_{4}, 5 \mathrm{~g} ; \mathrm{KH}_{2} \mathrm{PO}_{4}, 5 \mathrm{~g}$; $\mathrm{MgSO}_{4} \cdot 7 \mathrm{H}_{2} \mathrm{O}, 1.0 \mathrm{~g} ; \mathrm{KCl}, 0.5 \mathrm{~g} ; \mathrm{ZnSO}_{4} \cdot 7 \mathrm{H}_{2} \mathrm{O}, 0.01 \mathrm{~g} ; \mathrm{FeSO}_{4} \cdot 7 \mathrm{H}_{2} \mathrm{O}, 0.01 \mathrm{~g}$; and $\mathrm{MnSO}_{4} \cdot \mathrm{H}_{2} \mathrm{O}, 0.003 \mathrm{~g}$ per liter of distilled water. The initial $\mathrm{pH}$ of the medium was adjusted to 5.5 .

Cultivation Methods The slant culture was kept on PDA (potato dextrose agar) Difco. Spores of strains were prepared by growth on PDA slants for $14 \mathrm{~d}$ at $28^{\circ} \mathrm{C}$. Spores were washed with sterile water. A suspension of $10^{7}$ spores was used to incubate a 51 Erlenmeyer flask containing 21 inoculum medium, which was incubated at $28^{\circ} \mathrm{C}$ on a rotary shaker for $3 \mathrm{~d}$. This inoculum was then transferred to a 501 fermentor (B. Braun, Germany) containing 301 of synthetic medium, operated at $100 \mathrm{rpm}$ and $30^{\circ} \mathrm{C}$, with an aeration rate of $0.3 \mathrm{vvm}$. After $14 \mathrm{~d}$ of cultivation, the pellet mycelia harvested from the culture broth were used as samples for further extraction.

Extraction and Isolation The dried mycelia of the M. pilosus BCRC $38072(2 \mathrm{~kg})$ were extracted three times with $\mathrm{MeOH}$ at room temperature. The methanol syrup extract was partitioned between EtOAc and $\mathrm{H}_{2} \mathrm{O}(1: 1)$ to afford EtOAc $(2.5 \mathrm{~g})$ and $\mathrm{H}_{2} \mathrm{O}(10.2 \mathrm{~g})$ soluble fractions. The EtOAc-soluble fraction $(2.5 \mathrm{~g})$ was chromatographed over silica gel $(75 \mathrm{~g}, 70-230$ mesh), eluting with $n$-hexane and enriched with EtOAc to produce ten fractions (A1-A10). Fraction A4 $(0.56 \mathrm{~g})$ was subjected to a silica gel $(18 \mathrm{~g})$ chromatography by eluting with $n$-hexane-EtOAc $(100: 1)$, enriched with EtOAc, to furnish 20 fractions (A4-1-A4-20). Fraction A4-11 $(21.0 \mathrm{mg})$ was purified by preparative TLC ( $n$-hexane-EtOAc, $5: 1)$ to give monaspyranoindole $(3)(1.3 \mathrm{mg}),(4 R, 5 S)$-5-hydroxyhexan-4-olide $(6.2 \mathrm{mg})$, and ergosterol $(2.9 \mathrm{mg})$. Fraction A5 $(125.5 \mathrm{mg})$ was subjected to a silica gel $(3 \mathrm{~g})$ chromatography by eluting with $n$-hexane-EtOAc $(10: 1)$, enriched with EtOAc, to furnish 8 fractions (A5-1-A5-8). Fraction A5-4 (7.5 mg) was purified by preparative TLC ( $n$-hexane-EtOAc, $15: 1)$ to furnish monaspilosin (1) $(2.0 \mathrm{mg})$. Fraction A5-5 $(12.5 \mathrm{mg})$ was purified by preparative TLC $(n-$ hexane-EtOAc, $5: 1)$ to yield $\beta$-sitosteryl stearate $(4.0 \mathrm{mg})$, and linoleic acid $(9.8 \mathrm{mg})$. Fraction A6 $(214.3 \mathrm{mg})$, eluting with $n$-hexane-acetone $(20: 1)$, was further separated using silica gel column chromatography and preparative TLC ( $n$-hexane-EtOAc $(5: 1))$ and gave monaspiloindole (2) $(2.7 \mathrm{mg})$, $(Z)$-pulchellalactam $(21.7 \mathrm{mg}$ ), and a mixture of $\beta$-sitosterol and stigmasterol $(8.8 \mathrm{mg})$. Fraction A7 $(312.4 \mathrm{mg})$ was repeatedly chromatographed over silica gel and purified by preparative TLC to afford $p$-hydroxybenzoic acid (4.2 $\mathrm{mg}), 5$-(hydroxymethyl)furfural $(14.1 \mathrm{mg})$, and methylparaben $(2.5 \mathrm{mg})$. Fraction A9 $(290.3 \mathrm{mg})$ was chromatographed on a silica gel $(9 \mathrm{~g})$ column, eluting with $\mathrm{CHCl}_{3}$-EtOAc $(20: 1)$ to yield 12 fractions (A9-1-A9-12). Fraction A9-1 $(26.2 \mathrm{mg})$ was subjected to further silica gel column chromatography and purified by preparative TLC to afford trans-caffeic acid $(3.2 \mathrm{mg})$ and cyclo-(L-Pro-L-Tyr) $(4.1 \mathrm{mg})$.

Monaspilosin (1): Colorless oil. ${ }^{1} \mathrm{H}-\mathrm{NMR}\left(\mathrm{CDCl}_{3}, 400 \mathrm{MHz}\right)$ and ${ }^{13} \mathrm{C}-$ NMR $\left(\mathrm{CDCl}_{3}, 100 \mathrm{MHz}\right)$ : see Table 1. IR (Neat) $\mathrm{cm}^{-1}: 3403(\mathrm{OH}), 1712$ $(\mathrm{C}=\mathrm{O}), 1612,1514$ (aromatic ring $\mathrm{C}=\mathrm{C}$ stretch). $\mathrm{UV} \lambda_{\max }(\mathrm{MeOH}) \mathrm{nm}$ $(\log \varepsilon): 277$ (3.42). HR-ESI-MS $m / z 279.0997 \quad[\mathrm{M}+\mathrm{Na}]^{+}$(Calcd for $\left.\mathrm{C}_{16} \mathrm{H}_{16} \mathrm{O}_{3} \mathrm{Na}, 279.0995\right)$. ESI-MS $m / z 279[\mathrm{M}+\mathrm{Na}]^{+}$.

Monaspiloindole (2): Colorless oil. ${ }^{1} \mathrm{H}-\mathrm{NMR}\left(\mathrm{CDCl}_{3}, 400 \mathrm{MHz}\right)$ and ${ }^{13} \mathrm{C}-$ NMR $\left(\mathrm{CDCl}_{3}, 100 \mathrm{MHz}\right)$ : see Table 1. IR (Neat) $\mathrm{cm}^{-1}: 3410(\mathrm{OH}), 1716$ $(\mathrm{C}=\mathrm{O}), 1617,1517$ (aromatic ring $\mathrm{C}=\mathrm{C}$ stretch). $\mathrm{UV} \lambda_{\max }(\mathrm{MeOH}) \mathrm{nm}$ $(\log \varepsilon): 280$ (3.74). HR-ESI-MS $m / z \quad 302.1159 \quad[\mathrm{M}+\mathrm{Na}]^{+}$(Calcd for $\left.\mathrm{C}_{18} \mathrm{H}_{17} \mathrm{NO}_{2} \mathrm{Na}, 302.1157\right)$. ESI-MS $m / z 302[\mathrm{M}+\mathrm{Na}]^{+}$.

Monaspyranoindole (3): Colorless oil. ${ }^{1} \mathrm{H}-\mathrm{NMR}\left(\mathrm{CDCl}_{3}, 400 \mathrm{MHz}\right)$ and ${ }^{13} \mathrm{C}-\mathrm{NMR}\left(\mathrm{CDCl}_{3}, 100 \mathrm{MHz}\right)$ : see Table 1 . IR (Neat) $\mathrm{cm}^{-1}: 3320$ (NH). UV $\lambda_{\max }(\mathrm{MeOH}) \mathrm{nm}(\log \varepsilon): 288$ (3.60). HR-ESI-MS $m / z 224.3137[\mathrm{M}+\mathrm{Na}]^{+}$ (Calcd for $\left.\mathrm{C}_{13} \mathrm{H}_{15} \mathrm{NONa}, 224.3139\right)$. ESI-MS $m / z 224[\mathrm{M}+\mathrm{Na}]^{+}$.

Reduction of DPPH Radical After developing and drying, TLC plates were sprayed with a $0.2 \%$ DPPH (Aldrich-Sigma) solution in $\mathrm{MeOH}$. The plates were examined $30 \mathrm{~min}$ after spraying. Compounds showing a yellowon-purple spot were regarded as having antioxidant qualities. ${ }^{16)}$ The intensity of the yellow color depends upon the amount and nature of radical scavenger present in the sample.

Determination of the Scavenging Effect on DPPH Radical The radical scavenging activity of the test compounds was examined with the DPPH (2,2-diphenyl-1-picrylhydrazyl) radical, as described previously. ${ }^{17)} \alpha$-Tocopherol (=vitamin E) (Sigma) was used as control. Fifty microliters of a solution containing the different compounds (final concentration was $50 \mu \mathrm{M}$ ) to be tested was added to $5 \mathrm{ml}$ of a $1.0 \times 10^{-4} \mathrm{M} \mathrm{MeOH}$ solution of DPPH. The reaction mixture was shaken vigorously, and its absorbance at $517 \mathrm{~nm}$ was determined after $30 \mathrm{~min}$ incubation in a dark area. Decreasing DPPH solution absorbance indicates an increase in DPPH radical-scavenging activity. The DPPH solution, without sample solutions, was used as a control. All tests were run in triplicate and averaged. This activity is given as \% DPPH radical-scavenging and is calculated in the equation: \% DPPH radical-scavenging $=($ control absorbance - sample absorbance/control absorbance $) \times 100$.

Acknowledgements Support from the Ministry of Economic Affairs, Taiwan ROC, (Grant No. 94-EC-17-A-17-R7-0563) to the Food Industry Research and Development Institute (FIRDI) is appreciated.

\section{References}

1) Ma J., Li Y., Ye Q., Li J., Hua Y., Ju D., Zhang D., Cooper R., Chang M., J. Agric. Food Chem., 48, 5220-5225 (2000).

2) Tsuji K., Ichikawa T., Tanabe N., Abe S., Tarui S., Nakagawa Y., Nippon Nogeikagaku Kaishi, 66, 1241-1246 (1992).

3) Endo A., J. Antibiot., 32, 852-854 (1979).

4) Endo A., J. Med. Chem., 28, 401-405 (1985).

5) Martinokova L., Juzlova P., Vesely D., J. Appl. Bacteriol., 79, 609616 (1995)

6) Wong H. C., Bau Y. S., Plant Physiol., 60, 578-581 (1977).

7) Nozaki H., Date S., Kondo H., Kiyohara H., Takaoka D., Tada T., Nakayama M., Agric. Biol. Chem., 55, 899-900 (1991).

8) Blanc P. J., Loret M. O., Goma G., Biotechnol. Lett., 17, 291-294 (1995).

9) Juzlová P., Martinková L., Kren V., J. Industrial Microbiol., 16, 163170 (1996).

10) Sato K., Goda Y., Sakamoto S. S., Shibata H., Maitani T., Yamada T., Chem. Pharm. Bull., 45, 227-229 (1997).

11) Wild D., Tóth G., Humpf H. U., J. Agric. Food Chem., 50, 3999-4002 (2002).

12) Wild D., Tóth G., Humpf H. U., J. Agric. Food Chem., 51, 5493-5496 (2003).

13) Akihisa T., Mafune S., Ukiya M., Kimura Y., Yasukawa K., Suzuki T., Tokuda H., Tanabe N., Fukuoka T., J. Nat. Prod., 67, 479-480 (2004).

14) Jongrungruangchok S., Kittakoop P., Yongsmith B., Bavovada R., Tanasupawat S., Lartpornmatulee N., Thebtaranonth Y., Phytochemistry, 65, 2569-2575 (2004).

15) Akihisa T., Tokuda H., Yasukawa K., Ukiya M., Kiyota A., Sakamoto N., Suzuki T., Tanabe N., Nishino H., J. Agric. Food Chem., 53, 562565 (2005).

16) Cuendet M., Hostettman K., Potterat O., Dyatmiko W., Helv. Chim. Acta, 80, 1144-1152 (1997).

17) Hatano T., Edamatsu R., Hiramatsu M., Mori A., Fujita Y., Yasuhara T., Chem. Pharm. Bull., 37, 2016-2021 (1989).

18) Hahar L., Russell W. R., Middleton M., Shoeb M., Sarker S. D., Acta Pharm., 55, 187-193 (2005).

19) Yamamoto Y., Kurazono M., Bioorg. Med. Chem. Lett., 17, 16261628 (2007).

20) Zhang X., Li X., Lanter J. C., Sui Z., Organic Lett., 7, 2043-2046 (2005).

21) Caboni M. F., Iafelice G., Pelillo M., Marconi E., J. Agric. Food Chem., 53, 7465-7472 (2005).

22) Cheng M. J., Tsai I. L., Chen I. S., J. Chin. Chem. Soc., 50, 12411246 (2003).

23) Chiang H. C., Chu S. C., J. Chin. Chem. Soc., 38, 71-76 (1991).

24) Chang Y. C., Chang F. R., Wu Y. C., J. Chin. Chem. Soc., 47, 373380 (2000).

25) Chen C. Y., Wu Y. C., J. Chin. Chem. Soc., 48, 1203-1206 (2001).

26) Kuo Y. H., Lee S. M., Lai J. S., J. Chin. Chem. Soc., 47, 241-246 (2000).

27) Lee C. K., Chang M. H., J. Chin. Chem. Soc., 47, 555-560 (2000).

28) Stark T., Hofmann T., J. Agric. Food Chem., 53, 7222-7231 (2005).

29) Hearn T. W., Aust. J. Chem., 29, 107-113 (1976).

30) Bryans J. S., Chessum N. E. A., Huther N., Parsons A. F., Ghelfi F., Tetrahedron, 59, 6221-6232 (2003).

31) Buchanan M., Hashimoto T., Takaoka S., Asakawa Y., Phytochemistry, 40, 1251-1257 (1995). 